\title{
Detection of hepatitis B virus markers using a biosensor based on imaging ellipsometry
}

\author{
C. Qi, ${ }^{1,5}$ W. Zhu, ${ }^{2}$ Y. Niu, ${ }^{1,5}$ H. G. Zhang, ${ }^{3}$ G. Y. Zhu, ${ }^{4}$ Y. H. Meng, ${ }^{1,5}$ S. Chen ${ }^{1,5}$ and \\ G. Jin ${ }^{1}$ Institute of Mechanics, Chinese Academy of Sciences, Beijing; ${ }^{2}$ Radiation Medical Institute of Shandong Academy of Medical Sciences, Jinan; \\ ${ }^{3}$ Institute of Microcirculation, Peking Union Medical College \& Chinese Academy of Medical Science, Beijing; ${ }^{4}$ Deparment of Cardiology, Shandong \\ Provincial Hospital, Jinan; and ${ }^{5}$ Graduate University of Chinese Academy of Sciences, Beijing, China
}

Received December 2008; accepted for publication February 2009

SUMMARY. A biosensor based on imaging ellipsometry (BIE) has been developed and validated in 169 patients for detecting five markers of hepatitis B virus (HBV) infection. The methodology has been established to pave the way for clinical diagnosis, including ligand screening, determination of the sensitivity, set-up of cut-off values (CoVs) and comparison with other clinical methods. A matrix assay method was established for ligand screening. The CoVs of HBV markers were derived with the help of receiver operating characteristic curves. Enzyme-linked immunosorbent assay (ELISA) was the reference method. Ligands with high bioactivity were selected and sensitivities of $1 \mathrm{ng} / \mathrm{mL}$ and $1 \mathrm{IU} /$
$\mathrm{mL}$ for hepatitis B surface antigen (HBsAg) and surface antibody (anti-HBs) were obtained respectively. The CoVs of HBsAg, anti-HBs, hepatitis B e antigen, hepatitis B e antibody and core antibody were as follows: 15\%, 18\%, 15\%, $20 \%$ and $15 \%$, respectively, which were the percentages over the values of corresponding ligand controls. BIE can simultaneously detect up to five markers within $1 \mathrm{~h}$ with results in acceptable agreement with ELISA, and thus shows a potential for diagnosing hepatitis B with high throughput.

Keywords: hepatitis B, imaging ellipsometry, label-free biosensor, microfluidic.

\section{INTRODUCTION}

The detection of hepatitis B virus (HBV) markers is important clinical data for the diagnosis of infection with this virus [1]. Several methods, including enzyme-linked immunosorbent assay (ELISA), polymerase chain reaction, chip-based detection methods and surface plasmon resonance, have been used to detect HBV markers; however, they suffer from inherent limitations [2-5], such as

Abbreviations: anti-HBc, hepatitis B core antibody; anti-HBe, hepatitis B e antibody; anti-HBs, hepatitis B surface antibody; APTES, 3-aminopropyltriethoxy-silane; BIE, biosensor based on imaging ellipsometry; BSA, bovine serum albumin; CoVs, cut-off values; EDC, 1-(3-dimethylaminopropyl)-3-ethylcarbodiimide hydrochloride; ELISA, enzyme-linked immunosorbent assay; HBcAg, hepatitis B core antigen; HBeAg, hepatitis B e antigen; HBsAg, hepatitis B surface antigen; IE, imaging ellipsometry; NHS, N-hydroxysuccinimide; PBS, phosphate-buffered saline; PBST, phosphate-buffered saline with $1 \%$ Tween 20; ROCC, receiver operating characteristic curves.

Correspondence: Gang Jin, Graduate University of Chinese Academy of Sciences, \#19 Yu-quan Rd, Beijing 100049, China. E-mail: gajin@imech.ac.cn expensive equipment, specialist skills and complicated sample preparation processes. Conventional ELISA is still the main diagnostic test for hepatitis B [6], which has, however, some shortcomings, such as need of tracer labelling, indirect format of detection and length of testing time. Thus, a rapid, simple and direct method is an urgent need.

Compared with previous methods, biosensor based on imaging ellipsometry (BIE) offers several advantages such as a label-free rapid test, intuitionistic image, multiplexed analysis and low cost. The concept of biosensor usage in diagnosis was proposed in 1995 [7], and since then it has been successfully applied in the biomedical field, for example, in cancer marker detection, bacteria or virus detection, SARS antibody identification and so on [8-12]. Some initial results of hepatitis B detection have been reported, which show that BIE is feasible for clinical diagnosis of disease [13,14].

We report here on the BIE detection procedure for hepatitis B markers, including modifications and substrate, screening and immobilization of hepatitis B ligands, sensitivity, cut-off value ( $\mathrm{CoV})$ criteria, as well as testing of patient sera. A systematic hepatitis B markers detection method by means of BIE was thus established. 
Table 1 Clinical information of hepatitis B patients from Shandong Provincial Hospital

\begin{tabular}{|c|c|c|c|c|c|c|c|c|c|}
\hline \multirow{2}{*}{$\begin{array}{l}\text { Patients' } \\
\text { no. }\end{array}$} & \multirow[b]{2}{*}{ Age } & \multirow[b]{2}{*}{ Sex } & \multicolumn{5}{|c|}{$\begin{array}{l}\text { HBV markers ('+'is positive; '-' is negative: ' }+/- \text { ' } \\
\text { is uncertain) }\end{array}$} & \multirow[b]{2}{*}{ Time of sampling } & \multirow{2}{*}{$\begin{array}{l}\text { Time of ELISA } \\
\text { detection }\end{array}$} \\
\hline & & & HBsAg & $\mathrm{HBsAb}$ & $\mathrm{HBeAg}$ & $\mathrm{HBeAb}$ & $\mathrm{HBcAb}$ & & \\
\hline P001 & 47 & Woman & + & - & + & - & + & 14 December 2006 & 14 December 2006 \\
\hline P002 & 34 & Woman & + & - & - & + & + & 13 December 2006 & 14 December 2006 \\
\hline P003 & 22 & Woman & + & - & + & - & + & 13 December 2006 & 14 December 2006 \\
\hline P004 & 12 & Man & + & - & - & - & + & 14 December 2006 & 14 December 2006 \\
\hline P005 & 50 & Man & + & - & - & + & + & 14 December 2006 & 14 December 2006 \\
\hline P006 & 22 & Woman & + & - & + & - & - & 14 December 2006 & 14 December 2006 \\
\hline P007 & 27 & & + & - & + & - & + & 14 December 2006 & 14 December 2006 \\
\hline P008 & 43 & Woman & + & - & - & + & - & 13 December 2006 & 14 December 2006 \\
\hline P009 & 23 & Woman & + & - & + & - & - & 14 December 2006 & 14 December 2006 \\
\hline P010 & 25 & Woman & + & - & + & - & - & 14 December 2006 & 14 December 2006 \\
\hline P011 & 50 & Woman & + & - & - & + & + & 14 December 2006 & 14 December 2006 \\
\hline P012 & 21 & Woman & + & - & + & - & + & 15 December 2006 & 15 December 2006 \\
\hline P013 & 38 & Man & + & - & - & - & + & 15 December 2006 & 15 December 2006 \\
\hline P014 & 30 & Man & + & - & - & + & + & 15 December 2006 & 15 December 2006 \\
\hline P015 & 20 & Man & + & - & - & + & + & 15 December 2006 & 15 December 2006 \\
\hline P016 & 48 & Man & + & - & - & + & + & 15 December 2006 & 15 December 2006 \\
\hline P017 & & Woman & + & - & + & - & + & 15 December 2006 & 15 December 2006 \\
\hline P018 & 44 & Woman & + & - & - & + & + & 15 December 2006 & 15 December 2006 \\
\hline P019 & & Woman & + & - & - & + & + & 15 December 2006 & 15 December 2006 \\
\hline P020 & 62 & Man & + & - & - & + & + & 19 December 2006 & 19 December 2006 \\
\hline P021 & 56 & Woman & + & - & - & + & + & 19 December 2006 & 19 December 2006 \\
\hline $\mathrm{P} 022$ & 18 & Man & + & - & - & + & + & 19 December 2006 & 19 December 2006 \\
\hline P023 & 47 & Man & + & - & - & + & + & 19 December 2006 & 19 December 2006 \\
\hline P024 & 44 & Man & + & - & + & - & + & 19 December 2006 & 19 December 2006 \\
\hline P025 & 53 & Man & + & - & - & + & + & 19 December 2006 & 19 December 2006 \\
\hline P026 & 35 & Man & + & - & - & + & + & 19 December 2006 & 19 December 2006 \\
\hline P027 & 21 & Woman & + & - & - & + & + & 19 December 2006 & 19 December 2006 \\
\hline P028 & 52 & Man & + & - & - & - & + & 19 December 2006 & 19 December 2006 \\
\hline P029 & 66 & Woman & + & - & - & + & + & 19 December 2006 & 19 December 2006 \\
\hline P030 & 40 & Man & + & - & - & + & + & 20 December 2006 & 20 December 2006 \\
\hline P031 & 24 & Woman & + & - & - & - & + & 20 December 2006 & 20 December 2006 \\
\hline P032 & 20 & Woman & + & - & - & + & + & 20 December 2006 & 20 December 2006 \\
\hline P033 & 17 & Man & + & - & - & - & + & 20 December 2006 & 20 December 2006 \\
\hline P034 & 30 & Woman & + & - & - & + & + & 20 December 2006 & 20 December 2006 \\
\hline P035 & 31 & Woman & + & - & + & - & + & 20 December 2006 & 20 December 2006 \\
\hline P036 & 50 & Woman & + & - & - & + & + & 20 December 2006 & 20 December 2006 \\
\hline P037 & 42 & Man & + & - & - & + & + & 20 December 2006 & 20 December 2006 \\
\hline P038 & 34 & Woman & + & - & + & - & + & 20 December 2006 & 20 December 2006 \\
\hline P039 & 72 & Man & + & - & - & - & + & 20 December 2006 & 20 December 2006 \\
\hline P040 & 32 & Woman & + & - & - & + & + & 20 December 2006 & 20 December 2006 \\
\hline P041 & 60 & Man & + & - & - & - & + & 20 December 2006 & 20 December 2006 \\
\hline P042 & 32 & Man & + & - & - & + & + & 21 December 2006 & 21 December 2006 \\
\hline P043 & 20 & Woman & + & - & + & - & + & 21 December 2006 & 21 December 2006 \\
\hline P044 & 20 & Woman & + & - & + & - & + & 21 December 2006 & 21 December 2006 \\
\hline P045 & 30 & Man & + & - & - & + & + & 21 December 2006 & 21 December 2006 \\
\hline P046 & 38 & Man & $+/-$ & - & - & + & + & 21 December 2006 & 21 December 2006 \\
\hline P047 & 48 & Man & + & - & + & - & + & 21 December 2006 & 21 December 2006 \\
\hline P048 & 41 & Man & + & - & - & - & + & 21 December 2006 & 21 December 2006 \\
\hline P049 & 19 & Woman & + & - & + & - & + & 21 December 2006 & 21 December 2006 \\
\hline P050 & 18 & Woman & + & - & + & - & + & 21 December 2006 & 21 December 2006 \\
\hline
\end{tabular}


Table 1 (Continued)

\begin{tabular}{|c|c|c|c|c|c|c|c|c|c|}
\hline \multirow{2}{*}{$\begin{array}{l}\text { Patients' } \\
\text { no. }\end{array}$} & \multirow[b]{2}{*}{ Age } & \multirow[b]{2}{*}{ Sex } & \multicolumn{5}{|c|}{$\begin{array}{l}\text { HBV markers ('+'is positive; '-' is negative: '+/-' } \\
\text { is uncertain) }\end{array}$} & \multirow[b]{2}{*}{ Time of sampling } & \multirow{2}{*}{$\begin{array}{l}\text { Time of ELISA } \\
\text { detection }\end{array}$} \\
\hline & & & HBsAg & $\mathrm{HBsAb}$ & $\mathrm{HBeAg}$ & $\mathrm{HBeAb}$ & $\mathrm{HBcAb}$ & & \\
\hline P051 & 32 & Woman & + & - & - & + & + & 21 December 2006 & 21 December 2006 \\
\hline P052 & 67 & Woman & + & - & - & + & + & 21 December 2006 & 21 December 2006 \\
\hline P053 & 38 & Man & + & - & + & - & + & 22 December 2006 & 22 December 2006 \\
\hline P054 & 25 & Woman & + & - & - & + & + & 22 December 2006 & 22 December 2006 \\
\hline P055 & 26 & Man & + & - & + & - & + & 22 December 2006 & 22 December 2006 \\
\hline P056 & 58 & Man & + & - & - & - & + & 22 December 2006 & 22 December 2006 \\
\hline P057 & 53 & Man & + & - & + & - & + & 22 December 2006 & 22 December 2006 \\
\hline P058 & 37 & Woman & + & - & - & + & + & 22 December 2006 & 22 December 2006 \\
\hline P059 & 48 & Man & + & - & - & + & + & 26 December 2006 & 26 December 2006 \\
\hline P060 & 48 & Man & + & - & - & + & + & 1 January 2007 & 1 January 2007 \\
\hline
\end{tabular}

60 patients were detected with ELISA kit produced by Beijing Wantai Co Ltd.

Table 2 Clinical information of hepatitis B patients from Tientsin Blood Disease Hospital

\begin{tabular}{|c|c|c|c|c|c|c|c|c|}
\hline \multirow{2}{*}{$\begin{array}{l}\text { Patients' } \\
\text { no. }\end{array}$} & \multirow[b]{2}{*}{ Age } & \multicolumn{5}{|c|}{ HBV markers (ELISA OD/CoV) } & \multirow[b]{2}{*}{ Time of sampling } & \multirow{2}{*}{$\begin{array}{l}\text { Time of ELISA } \\
\text { detection }\end{array}$} \\
\hline & & HBsAg & $\mathrm{HBsAb}$ & $\mathrm{HBeAg}$ & $\mathrm{HBeAb}$ & $\mathrm{HBcAb}$ & & \\
\hline 1 & 52 & 0.36 & 33.70 & 0.08 & 0.29 & 0.02 & 21 December 2006 & 22 December 2006 \\
\hline 2 & 40 & 0.41 & 11.10 & 0.14 & 1.73 & 0.30 & 21 December 2006 & 22 December 2006 \\
\hline 3 & 25 & 7.51 & 0.14 & 0.13 & 0.01 & 0.10 & 21 December 2006 & 22 December 2006 \\
\hline 4 & 53 & 5.71 & 0.08 & 0.08 & 0.73 & 0.02 & 21 December 2006 & 22 December 2006 \\
\hline 5 & 58 & 0.15 & 30.90 & 0.08 & 0.70 & 0.03 & 21 December 2006 & 22 December 2006 \\
\hline 6 & 61 & 0.10 & 21.70 & 0.13 & 0.13 & 0.03 & 21 December 2006 & 22 December 2006 \\
\hline 8 & 63 & 0.25 & 3.77 & 0.14 & 0.45 & 0.06 & 21 December 2006 & 22 December 2006 \\
\hline 9 & 46 & 43.80 & 0.08 & 0.08 & 1.52 & 0.01 & 22 December 2006 & 25 December 2006 \\
\hline 10 & 75 & 0.21 & 41.70 & 0.98 & 0.03 & 0.42 & 23 December 2006 & 25 December 2006 \\
\hline 11 & 54 & 37.50 & 0.11 & 31.90 & 1.69 & 0.01 & 23 December 2006 & 25 December 2006 \\
\hline 12 & 51 & 42.90 & 0.10 & 0.10 & 0.02 & 0.01 & 23 December 2006 & 25 December 2006 \\
\hline 13 & 30 & 38.60 & 0.98 & 30.70 & 1.01 & 0.01 & 23 December 2006 & 25 December 2006 \\
\hline 14 & 49 & 42.70 & 0.10 & 0.10 & 2.11 & 0.01 & 23 December 2006 & 25 December 2006 \\
\hline 15 & 64 & 23.70 & 0.24 & 6.87 & 2.87 & 0.03 & 23 December 2006 & 25 December 2006 \\
\hline 16 & 69 & 38.40 & 0.18 & 0.65 & 1.83 & 0.01 & 23 December 2006 & 25 December 2006 \\
\hline 17 & 40 & 40.90 & 0.12 & 0.11 & 0.17 & 0.01 & 23 December 2006 & 25 December 2006 \\
\hline 19 & 46 & 48.50 & 0.17 & 37.90 & 1.80 & 0.03 & 24 December 2006 & 25 December 2006 \\
\hline 20 & 69 & 48.90 & 0.21 & 0.05 & 0.60 & 0.01 & 24 December 2006 & 25 December 2006 \\
\hline 21 & 39 & 45.30 & 0.08 & 0.32 & 1.03 & 0.01 & 24 December 2006 & 25 December 2006 \\
\hline 22 & 60 & 0.11 & 3.47 & 0.19 & 0.69 & 0.05 & 25 December 2006 & 26 December 2006 \\
\hline 23 & 57 & 24.20 & 0.07 & 0.20 & 0.02 & 0.42 & 25 December 2006 & 26 December 2006 \\
\hline 24 & 19 & 13.60 & 0.06 & 18.90 & 1.01 & 0.02 & 25 December 2006 & 26 December 2006 \\
\hline 25 & 41 & 25.30 & 0.74 & 19.20 & 1.01 & 0.01 & 26 December 2006 & 27 December 2006 \\
\hline 26 & 47 & 0.11 & 20.20 & 0.24 & 0.55 & 0.99 & 26 December 2006 & 27 December 2006 \\
\hline 27 & 50 & 0.11 & 34.90 & 0.03 & 0.02 & 0.02 & 26 December 2006 & 27 December 2006 \\
\hline 28 & 56 & 15.50 & 0.01 & 0.20 & 0.51 & 0.01 & 26 December 2006 & 27 December 2006 \\
\hline 29 & 32 & 0.49 & 26.50 & 0.10 & 0.47 & 0.01 & 26 December 2006 & 27 December 2006 \\
\hline 30 & 64 & 27.50 & 0.23 & 0.16 & 0.02 & 0.02 & 28 December 2006 & 28 December 2006 \\
\hline 31 & 34 & 35.40 & 0.13 & 0.21 & 0.01 & 0.01 & 28 December 2006 & 28 December 2006 \\
\hline 32 & 54 & 39.70 & 0.21 & 8.35 & 1.24 & 0.02 & 28 December 2006 & 28 December 2006 \\
\hline 33 & 56 & 0.11 & 2.79 & 0.88 & 0.49 & 0.19 & 28 December 2006 & 28 December 2006 \\
\hline 34 & 50 & 0.11 & 21.90 & 0.08 & 0.02 & 0.02 & 28 December 2006 & 28 December 2006 \\
\hline
\end{tabular}


Table 2 (Continued)

\begin{tabular}{|c|c|c|c|c|c|c|c|c|}
\hline \multirow{2}{*}{$\begin{array}{l}\text { Patients' } \\
\text { no. }\end{array}$} & \multirow[b]{2}{*}{ Age } & \multicolumn{5}{|c|}{ HBV markers (ELISA OD/CoV) } & \multirow[b]{2}{*}{ Time of sampling } & \multirow{2}{*}{$\begin{array}{l}\text { Time of ELISA } \\
\text { detection }\end{array}$} \\
\hline & & HBsAg & $\mathrm{HBsAb}$ & $\mathrm{HBeAg}$ & $\mathrm{HBeAb}$ & $\mathrm{HBcAb}$ & & \\
\hline 35 & 61 & 41.30 & 0.08 & 0.09 & 0.01 & 0.01 & 28 December 2006 & 28 December 2006 \\
\hline 36 & 41 & 38.90 & 0.29 & 0.10 & 0.02 & 0.03 & 28 December 2006 & 29 December 2006 \\
\hline 37 & 49 & 0.08 & 7.50 & 0.01 & 1.16 & 0.82 & 28 December 2006 & 29 December 2006 \\
\hline 38 & 21 & 26.80 & 0.18 & 7.28 & 1.01 & 0.03 & 28 December 2006 & 29 December 2006 \\
\hline 39 & 51 & 0.06 & 0.14 & 0.01 & 0.34 & 0.03 & 28 December 2006 & 29 December 2006 \\
\hline 40 & 28 & 0.04 & 5.83 & 0.06 & 0.01 & 0.02 & 29 December 2006 & 29 December 2006 \\
\hline 41 & 23 & 37.70 & 0.12 & 0.11 & 0.70 & 0.02 & 30 December 2006 & 30 December 2006 \\
\hline 42 & 70 & 0.24 & 37.20 & 0.18 & 0.05 & 0.99 & 30 December 2006 & 30 December 2006 \\
\hline 43 & 42 & 0.11 & 0.18 & 0.12 & 0.58 & 0.05 & 29 December 2006 & 29 December 2006 \\
\hline 44 & 30 & 0.09 & 41.60 & 0.15 & 0.15 & 0.48 & 30 December 2006 & 30 December 2006 \\
\hline 45 & 73 & 0.19 & 1.85 & 0.04 & 0.77 & 0.01 & 30 December 2006 & 30 December 2006 \\
\hline 46 & 54 & 35.80 & 0.08 & 0.08 & 0.01 & 0.01 & 31 December 2006 & 31 December 2006 \\
\hline 47 & 41 & 19.20 & 0.10 & 6.32 & 1.01 & 0.11 & 31 December 2006 & 31 December 2006 \\
\hline 48 & 49 & 39.80 & 0.16 & 0.11 & 0.02 & 0.01 & 31 December 2006 & 31 December 2006 \\
\hline 49 & 41 & 0.01 & 4.38 & 0.04 & 0.60 & 0.01 & 31 December 2006 & 31 December 2006 \\
\hline 50 & 42 & 0.05 & 0.45 & 0.03 & 0.01 & 0.39 & 1 January 2007 & 1 January 2007 \\
\hline 51 & 41 & 43.40 & 0.04 & 0.19 & 0.51 & 0.01 & 1 January 2007 & 1 January 2007 \\
\hline 52 & 36 & 0.03 & 14.70 & 0.01 & 1.02 & 0.07 & 1 January 2007 & 1 January 2007 \\
\hline 53 & 60 & 0.19 & 3.01 & 0.12 & 0.97 & 0.48 & 4 January 2007 & 4 January 2007 \\
\hline 54 & 50 & 0.21 & 21.70 & 0.14 & 0.02 & 0.01 & 4 January 2007 & 4 January 2007 \\
\hline 55 & 42 & 32.00 & 0.10 & 0.04 & 0.01 & 0.01 & 4 January 2007 & 4 January 2007 \\
\hline 56 & 55 & 45.60 & 0.19 & 0.32 & 0.62 & 0.01 & 4 January 2007 & 4 January 2007 \\
\hline 57 & 50 & 36.90 & 0.06 & 0.44 & 0.83 & 0.02 & 4 January 2007 & 4 January 2007 \\
\hline 58 & 27 & 39.50 & 0.13 & 0.13 & 0.01 & 0.02 & 4 January 2007 & 4 January 2007 \\
\hline 59 & 28 & 38.90 & 0.08 & 0.10 & 0.01 & 0.01 & 4 January 2007 & 4 January 2007 \\
\hline 60 & 23 & 13.10 & 0.05 & 13.30 & 1.01 & 0.02 & 4 January 2007 & 4 January 2007 \\
\hline 61 & 52 & 0.26 & 4.66 & 0.04 & 0.01 & 0.01 & 4 January 2007 & 4 January 2007 \\
\hline 62 & 44 & 0.00 & 21.40 & 0.05 & 0.49 & 0.01 & 1 January 2007 & 1 January 2007 \\
\hline 63 & 48 & 0.04 & 20.80 & 0.07 & 0.07 & 0.01 & 4 January 2007 & 4 January 2007 \\
\hline 64 & 34 & 12.80 & 0.09 & 7.67 & 1.01 & 0.01 & 4 January 2007 & 4 January 2007 \\
\hline 65 & 44 & 41.30 & 0.08 & 0.48 & 0.62 & 0.01 & 4 January 2007 & 4 January 2007 \\
\hline 66 & 62 & 38.90 & 0.06 & 0.10 & 0.14 & 0.01 & 4 January 2007 & 4 January 2007 \\
\hline 67 & 54 & 0.12 & 25.80 & 0.03 & 0.48 & 0.01 & 4 January 2007 & 4 January 2007 \\
\hline 68 & 50 & 0.21 & 31.60 & 0.12 & 0.02 & 0.03 & 4 January 2007 & 4 January 2007 \\
\hline 69 & 45 & 0.07 & 19.20 & 0.06 & 0.34 & 0.03 & 4 January 2007 & 4 January 2007 \\
\hline 70 & 46 & 0.10 & 30.40 & 0.12 & 0.01 & 0.01 & 4 January 2007 & 4 January 2007 \\
\hline 71 & 60 & 0.12 & 37.90 & 0.14 & 0.02 & 0.01 & 4 January 2007 & 4 January 2007 \\
\hline 72 & 65 & 0.08 & 14.10 & 0.04 & 0.43 & 0.59 & 4 January 2007 & 4 January 2007 \\
\hline 73 & 58 & 0.11 & 45.30 & 0.08 & 0.37 & 0.01 & 4 January 2007 & 4 January 2007 \\
\hline 74 & 45 & 39.00 & 0.17 & 0.10 & 0.09 & 0.01 & 5 January 2007 & 5 January 2007 \\
\hline 75 & 52 & 0.12 & 23.20 & 0.13 & 0.05 & 0.02 & 5 January 2007 & 5 January 2007 \\
\hline 76 & 50 & 0.10 & 2.90 & 0.11 & 1.01 & 0.35 & 5 January 2007 & 5 January 2007 \\
\hline 77 & l & 0.08 & 3.06 & 0.09 & 0.32 & 0.38 & 5 January 2007 & 5 January 2007 \\
\hline 78 & 46 & 44.60 & 0.08 & 0.08 & 0.01 & 0.01 & 5 January 2007 & 5 January 2007 \\
\hline 79 & 61 & 0.01 & 6.70 & 0.01 & 0.01 & 0.01 & 5 January 2007 & 5 January 2007 \\
\hline 80 & 58 & 44.30 & 0.03 & 0.07 & 0.01 & 0.01 & 5 January 2007 & 5 January 2007 \\
\hline 81 & 43 & 0.30 & 30.00 & 0.04 & 0.02 & 0.37 & 5 January 2007 & 5 January 2007 \\
\hline 82 & 44 & 0.15 & 6.63 & 0.13 & 0.67 & 0.04 & 4 January 2007 & 4 January 2007 \\
\hline 83 & 62 & 0.14 & 7.33 & 0.15 & 1.56 & 0.04 & 5 January 2007 & 5 January 2007 \\
\hline 84 & / & 0.16 & 0.37 & 0.10 & 0.35 & 0.22 & 5 January 2007 & 5 January 2007 \\
\hline 85 & 49 & 0.17 & 0.42 & 0.06 & 0.04 & 0.44 & 5 January 2007 & 5 January 2007 \\
\hline
\end{tabular}


Table 2 (Continued)

\begin{tabular}{|c|c|c|c|c|c|c|c|c|}
\hline \multirow{2}{*}{$\begin{array}{l}\text { Patients' } \\
\text { no. }\end{array}$} & \multirow[b]{2}{*}{ Age } & \multicolumn{5}{|c|}{ HBV markers (ELISA OD/CoV) } & \multirow[b]{2}{*}{ Time of sampling } & \multirow{2}{*}{$\begin{array}{l}\text { Time of ELISA } \\
\text { detection }\end{array}$} \\
\hline & & HBsAg & $\mathrm{HBsAb}$ & HBeAg & $\mathrm{HBeAb}$ & $\mathrm{HBcAb}$ & & \\
\hline 86 & 40 & 0.06 & 40.60 & 0.11 & 0.02 & 0.14 & 5 January 2007 & 5 January 2007 \\
\hline 87 & 47 & 0.06 & 32.70 & 0.09 & 1.10 & 0.01 & 8 January 2007 & 8 January 2007 \\
\hline 88 & 36 & 0.09 & 37.30 & 0.10 & 0.05 & 1.78 & 8 January 2007 & 8 January 2007 \\
\hline 89 & 45 & 49.10 & 0.10 & 0.09 & 0.01 & 0.16 & 8 January 2007 & 8 January 2007 \\
\hline 90 & 70 & 17.90 & 0.15 & 0.11 & 0.06 & 0.03 & 8 January 2007 & 8 January 2007 \\
\hline 92 & 73 & 51.30 & 0.04 & 0.38 & 0.99 & 0.01 & 8 January 2007 & 8 January 2007 \\
\hline 93 & 79 & 0.14 & 11.30 & 0.06 & 0.11 & 0.14 & 8 January 2007 & 8 January 2007 \\
\hline 94 & 37 & 0.10 & 27.30 & 0.08 & 1.14 & 0.07 & 8 January 2007 & 8 January 2007 \\
\hline 95 & 54 & 0.41 & 39.50 & 0.13 & 0.01 & 0.01 & 8 January 2007 & 8 January 2007 \\
\hline 96 & 47 & 0.19 & 32.20 & 0.08 & 0.05 & 0.02 & 8 January 2007 & 8 January 2007 \\
\hline 97 & 55 & 0.25 & 37.60 & 0.10 & 0.56 & 0.05 & 8 January 2007 & 8 January 2007 \\
\hline 98 & 44 & 0.14 & 20.10 & 0.18 & 0.76 & 0.22 & 8 January 2007 & 8 January 2007 \\
\hline 99 & 30 & 22.40 & 0.30 & 46.80 & 1.01 & 0.02 & 8 January 2007 & 8 January 2007 \\
\hline 100 & 66 & 33.60 & 0.30 & 0.23 & 0.01 & 0.01 & 8 January 2007 & 8 January 2007 \\
\hline 101 & 46 & 0.13 & 37.10 & 0.25 & 0.38 & 0.02 & 9 January 2007 & 9 January 2007 \\
\hline 102 & 31 & 18.70 & 0.22 & 37.40 & 1.01 & 0.17 & 9 January 2007 & 9 January 2007 \\
\hline 103 & 34 & 31.20 & 0.13 & 0.20 & 0.45 & 0.01 & 9 January 2007 & 9 January 2007 \\
\hline 104 & 36 & 0.11 & 0.98 & 0.20 & 0.01 & 0.31 & 9 January 2007 & 9 January 2007 \\
\hline 105 & 59 & 33.60 & 0.09 & 0.18 & 0.88 & 0.06 & 9 January 2007 & 9 January 2007 \\
\hline 106 & 59 & 30.80 & 0.13 & 0.07 & 0.04 & 0.02 & 9 January 2007 & 9 January 2007 \\
\hline 107 & 43 & 0.25 & 34.50 & 0.07 & 0.44 & 0.01 & 11 January 2007 & 11 January 2007 \\
\hline 108 & 24 & 35.90 & 0.13 & 20.50 & 0.41 & 0.90 & 11 January 2007 & 11 January 2007 \\
\hline 109 & 65 & 0.25 & 25.40 & 0.21 & 0.60 & 0.22 & 11 January 2007 & 11 January 2007 \\
\hline 110 & 55 & 64.00 & 0.18 & 0.14 & 0.01 & 0.01 & 11 January 2007 & 11 January 2007 \\
\hline 111 & 33 & 39.00 & 0.25 & 0.02 & 0.01 & 0.01 & 11 January 2007 & 11 January 2007 \\
\hline 112 & 53 & 0.06 & 1.02 & 0.01 & 0.10 & 0.71 & 10 January 2007 & 10 January 2007 \\
\hline
\end{tabular}

109 patients (absence of patients' no.: 7, 18, 91) were detected by ELISA kit produced by Shanghai Rongsheng Biotech CoLtd. The absence of information was marked as ' $\%$. ELISA OD/CoV of HBV markers was presented. If the value of HBeAg, HBsAb and HBsAg detected with noncompetitive ELISA method was equal or greater than 1 , the result was considered as positive. If the value of $\mathrm{HBcAb}$ and $\mathrm{HBeAb}$ detected with competitive ELISA method was equal or lesser than 1, the result was considered as positive.

\section{PATIENTS AND METHODS}

\section{Study subjects, sample collection and reagents}

Silicon wafers were purchased from the Luoyang Monocrystalline Silicon Factory (Luo, China). $\mathrm{H}_{2} \mathrm{O}_{2}(30 \%), \mathrm{H}_{2} \mathrm{SO}_{4}$ $(98 \%)$ and absolute ethanol were purchased from Beijing Bei Hua Fine Chemicals Co Ltd (Beijing, China). 3-Aminopropyltriethoxy-silane (APTES, 99\%, v/v), 1-(3-dimethylaminopropyl)-3-ethylcarbodiimide hydrochloride (EDC) and N-hydroxysuccinimide (NHS) were purchased from ACROS (Acros Organics, Geel, Belgium). Succinic anhydride was purchased from Beijing Hengye Zhongyuan Chemical Co Ltd (Beijing, China). All chemicals were of analytical grade. Hepatitis B surface antigen (HBsAg), hepatitis B surface antibody (anti-HBs), hepatitis B core antigen ( $\mathrm{HBcAg}$ ), hepatitis B core antibody (anti-HBc), hepatitis B e antigen
(HBeAg) and hepatitis B e antibody (anti-HBe) ligands were purchased from Beijing Hotgen Biotechnology Co Ltd (China). Anti-HBs and HBsAg national reference samples (1 and $2 \mathrm{ng} / \mathrm{mL}$ respectively) were purchased from the National Institute for the Control of Pharmaceutical and Biological Products (Beijin, China). All sera with available ELISA results were from Shandong Provincial Hospital and Tientsin Blood Disease Hospital (China). ELISA kits were purchased from Beijing Wantai Biological Pharmacy Enterprise Co Ltd (authorized no.: S10980089) and Shanghai Rongsheng Biotech Co Ltd (S10950044) (China). Patient demographic data can be found in Tables 1 and 2. Tween 20 and bovine serum albumin (BSA) were purchased from Sigma Aldrich (St Louis, MO, USA), phosphate-buffered saline (PBS, $140 \mathrm{mM} \mathrm{NaCl}, 2.7 \mathrm{~mm} \mathrm{KCl}, 10 \mathrm{~mm} \mathrm{Na} \mathrm{HPO}_{4}$, $1.8 \mathrm{~mm} \mathrm{KH}_{2} \mathrm{PO}_{4}, \mathrm{pH} 7.3$ ), PBS with $1 \%$ Tween 20 (PBST) and NE (0.05 mol/mL NHS, $0.2 \mathrm{~mol} / \mathrm{mL} \mathrm{EDC})$ were prepared 
(a)

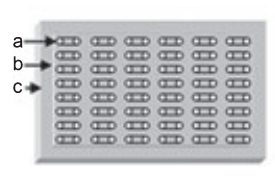

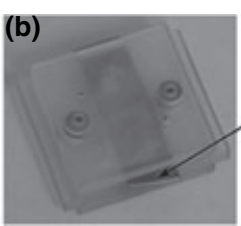
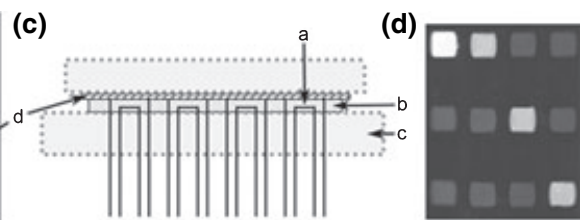

Fig. 1 Microfluidic system. (a) Micro-reaction interface; (b) module for microarray; (c) schematic illustration of the microfluidic system; (d) a sample of protein microarray prepared by using the microfluidic system and grey-scale image obtained using IE. 'a' is small cell; 'b' is polydimethyl-siloxane film; 'c' is organic glass with small holes; 'd' is silicon wafer.

in deionized water $(18.3 \mathrm{M} \Omega \mathrm{cm}$, Milli-Q plus system; Millipore, Bedford, MA, USA).

\section{BIE detection procedure and principle}

First, silicon wafers were chosen as the substrate and modified by chemical reagents forming reactive groups on its surface. Second, the modified substrate was put in a microfluidic system and its surface was patterned in an array format. Hepatitis B ligands were immobilized in different areas. Third, sera were passed through the ligand areas and hepatitis B markers were captured. Finally, the wafer was taken from the microfluidic system and placed in the imaging ellipsometry (IE) apparatus to analyse the results.

Imaging ellipsometry is a display technique for ultrathin film and surface characterization $[15,16]$. The incident wave of polarized light beam used as probe irradiates the substrate and is thus modified, which makes the reflective or transmission beam carry relevant sample information, for example, protein surface concentration. When IE detects a biomolecule layer, the value of reflection intensity is presented in greyscale. The variation of surface concentrations causes changes in the grey-scale value, which reflects directly the molecule mass surface concentration on the substrate. To visualize its variation across layers, the result can also be transformed to represent the corresponding distribution in three dimensions.

\section{Substrate surface modification}

The hydrophilic and hydrophobic modifications were the same as in previous studies [10]. After hydrophobic modification with APTES, a layer of densely packed amino groups is formed on the substrate [11]. After rinsing in ethanol, the (a)

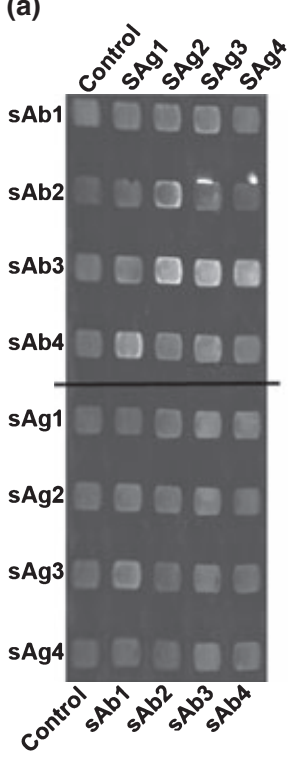

(b)

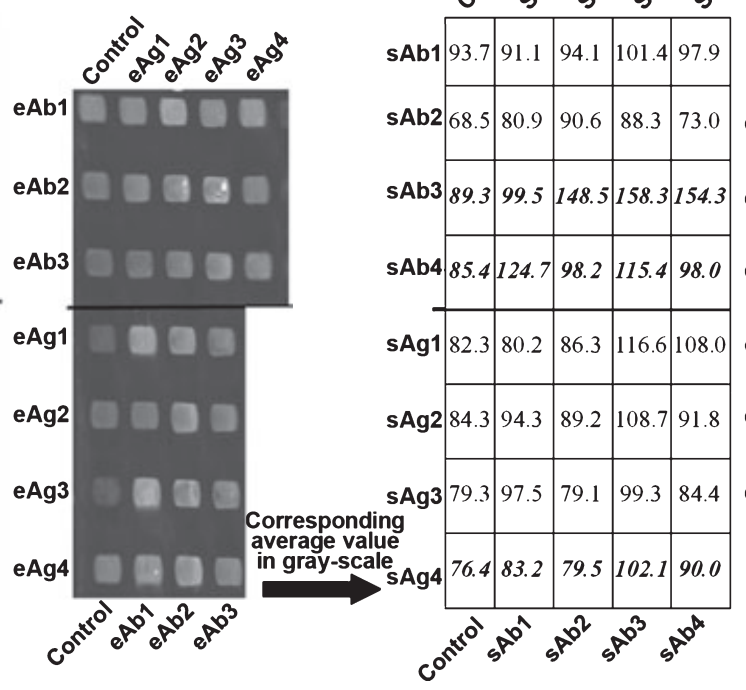

(b)

(a)

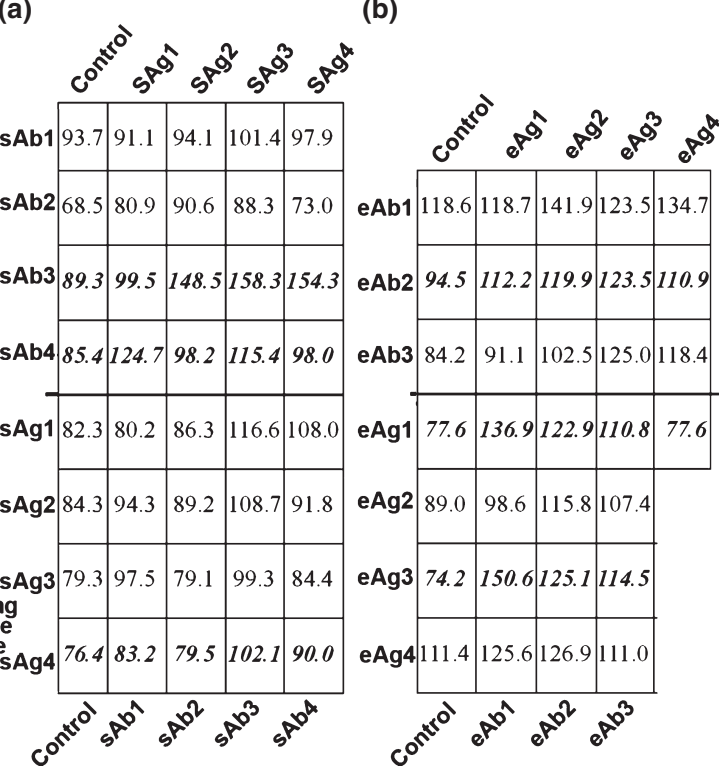

Fig. 2 Screening of hepatitis B ligands. (a) Screening of anti-HBs and HBsAg. Different lots of anti-HBs and HBsAg ligands were firstly immobilized in different lines. After blocking with BSA, the first row was used as control. Different lots of HBsAg and anti-HBs markers were detected in different rows. (b) Screening for anti-HBe and HBeAg. Anti-HBe and HBeAg ligands were immobilized in different lines. After blocking with BSA, the first row was used as control. Different lots of HBeAg and anti-HBe markers were detected in different rows. The italics indicate results with the largest variation in grey-scale value, which in turn indicate that the ligands had higher bioactivity. 
substrate is incubated in saturated succinic anhydride solution in ethanol for $3 \mathrm{~h}$. The $\mathrm{CH}_{2} \mathrm{CH}_{2} \mathrm{COOCO}$ of succinic anhydride reacts with the $-\mathrm{NH}_{2}$ groups immobilized on the substrate and generates $-\left(\mathrm{CH}_{2}\right)_{3} \mathrm{NH}-\mathrm{CO}\left(\mathrm{CH}_{2}\right)_{2}-\mathrm{COOH}$. After rinsing in ethanol, the substrate is kept in ethanol. Some carboxyl groups are formed on the substrate, which could be activated by NE (NHS and EDC) for ligand or protein immobilization. In the presence of NHS, EDC can transfer carboxyl groups to Sulfo-NHS ester, which can react with the $-\mathrm{NH}_{2}$ groups of protein to immobilize hepatitis $\mathrm{B}$ ligands covalently.

\section{Substrate pattern and immobilization of hepatitis B ligands}

Hepatitis B ligands can be patterned homogeneously and simultaneously on the substrate in an array format by the microfluidic system (Fig. 1). The physical size of the patterned site is about $1.5 \times 1 \mathrm{~mm}^{2}$. With simple microfluidic channel junction, the microfluidic array can be used in serial or parallel formats to analyse single or multiple samples simultaneously [14].

\section{Hepatitis B ligand screening with matrix assay}

Hepatitis B ligands were immobilized on the substrate in an array format, and then their bioactivities were checked with corresponding hepatitis B markers. The process for checking the bioactivities of anti-HBs and HBsAg ligands was as follows. After carboxyl activation with NE $(10 \mu \mathrm{L} /$ area), the anti-HBs and HBsAg ligands were added to the microfluidic system $(0.1 \mathrm{mg} / \mathrm{mL}, 10 \mu \mathrm{L} /$ area, passing the substrate with a flowrate of $2 \mu \mathrm{L} / \mathrm{min}$ for $5 \mathrm{~min}$ ). All areas were blocked with $10 \mathrm{mg} / \mathrm{mL}$ BSA for $30 \mathrm{~min}$, and then some areas were chosen as control to add PBST buffer. In other areas, the corresponding pure HBsAg and anti-HBs markers were added to interact with the corresponding ligands immobilized on the substrate. These areas were rinsed with deionized water between consecutive operation steps. Then, the substrate was taken out of the microfluidic system and its surface was rinsed with deionized water. After blowing nitrogen, the result was read and analysed by IE. When the same hepatitis $B$ marker reacted with different ligands, the results exhibited different values in the greyscale, which indicated that the ligands had different bioactivities.

\section{Sensitivity}

Anti-HBs was immobilized in six areas. All areas were blocked for $30 \mathrm{~min}$ with a negative serum sample (diluted 1:1 v/v with PBST). Sensing surface areas with anti-HBs were formed for HBsAg marker detection. Two areas were chosen to detect $\mathrm{HBs} \mathrm{g}$ from the national positive reference sample (1 ng/mL), and two other areas were chosen to detect the national HBsAg-negative reference sample as negative control. The remaining two areas were chosen to add PBST as blank control. National positive, negative reference samples and PBST were added ( $20 \mu \mathrm{L} /$ area, $2 \mu \mathrm{L} / \mathrm{min}$ and $10 \mathrm{~min}$ respectively) and the results were read by IE.

\section{Serum detection and CoVs}

Five hepatitis $\mathrm{B}$ ligands (HBsAg, $\mathrm{HBeAg}$ and $\mathrm{HBcAg}$ : $0.3 \mathrm{mg} / \mathrm{mL}$, anti-HBs and anti-HBe: $0.1 \mathrm{mg} / \mathrm{mL}$ ) were immobilized in five rows. All areas were blocked with negative serum reference sample for $30 \mathrm{~min}$. Different lines were chosen to detect different sera (diluted 1:15 with PBST, $20 \mu \mathrm{L} /$ area). CoV of each marker was analysed by referring to receiver operating characteristic curves (ROCC) [17], and ELISA was used as reference test criterion. Each 96-well micro-titre ELISA plate was coated with a particular kind of hepatitis B ligand. Two wells were used as positive and negative controls, respectively, and one well was used as blank control. Other wells were used to detect sera. The remaining steps were as in the instruction manual of the ELISA kit.
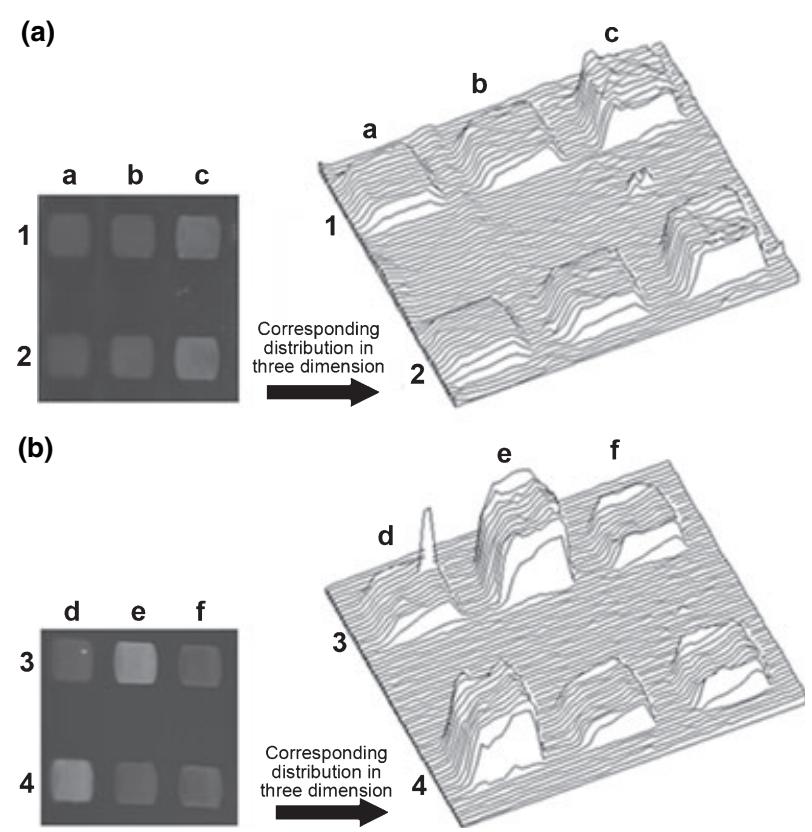

Fig. 3 Sensitivity of BIE. (a) Sensitivity in detecting HBsAg. The anti-HBs ligand was immobilized in six areas. After blocking with the national HBsAg reference negative sample, HBsAg-positive reference samples with $1 \mathrm{ng} / \mathrm{mL}$ were detected in area 'c1' and 'c2', and HBsAg reference negative samples used as negative control were detected in 'b1' and 'b2'. PBST, used as blank control, was added to 'a1' and 'b1'. (b) Sensitivity in detecting anti-HBs. The anti-HBs positive reference sample with $1 \mathrm{IU} / \mathrm{mL}$ was detected in 'd4' and 'e3', whilst the negative samples were detected in ' $\mathrm{d} 3$ ' and 'e4'. PBST was added to 'f3' and 'f4'. 


\section{RESULTS}

\section{Hepatitis B high bioactive ligand screening}

To achieve high detection rates, we selected ligands that could interact with most of the corresponding markers. From the analysis of grey-scale values, high bioactive anti-HBs ligands are in lines 3 and 4, and HBsAg in line 8 (Fig. 2a). A high bioactive anti-HBe ligand is seen in line 10, and HBeAg in lines 12 and 14 (Fig. 2b). HBcAg ligand can also be screened in a similar fashion.

\section{Sensitivity}

The sensitivity in detecting HBsAg reached $1 \mathrm{ng} / \mathrm{mL}$ (Fig. 3a). The value in greyscale for the blank control (area a1 and a2) was $63.3 \pm 0.1$. The value for the negative control (area b1 and b2) was $66.7 \pm 1.7$, about $5 \%$ higher than that of the blank control. The value for the positive sample ( $1 \mathrm{ng} / \mathrm{mL}$, subtype ad, area $\mathrm{c} 1$ and $\mathrm{c} 2)$ was $83.4 \pm 0.4$, about $31.8 \%$ and $25.0 \%$ higher than the blank and negative control respectively, which indicated that a sample of the order of $1 \mathrm{ng} / \mathrm{mL}$ could be detected. The sensitivity of anti-HBs was also tested (Fig. 3b). The values for the blank control, negative control and positive sample were $69.5 \pm 1.0, \quad 70.0 \pm 0.2$ and $113.9 \pm 1.3$ respectively, suggesting that the sensitivity might be better than $1 \mathrm{IU} / \mathrm{mL}$.

\section{Clinical hepatitis B serum detection}

Sixty hepatitis B patients (Table 1) with qualitative results by ELISA were tested with BIE and an automatic BIE operation process was established as follows: immobiliza-
Fig. 4 Comparison of HBsAg detection by BIE (- -) and by ELISA (- $\Delta-$ ). (a) Original image; (b) enlarged image of the lowest part of image (a).
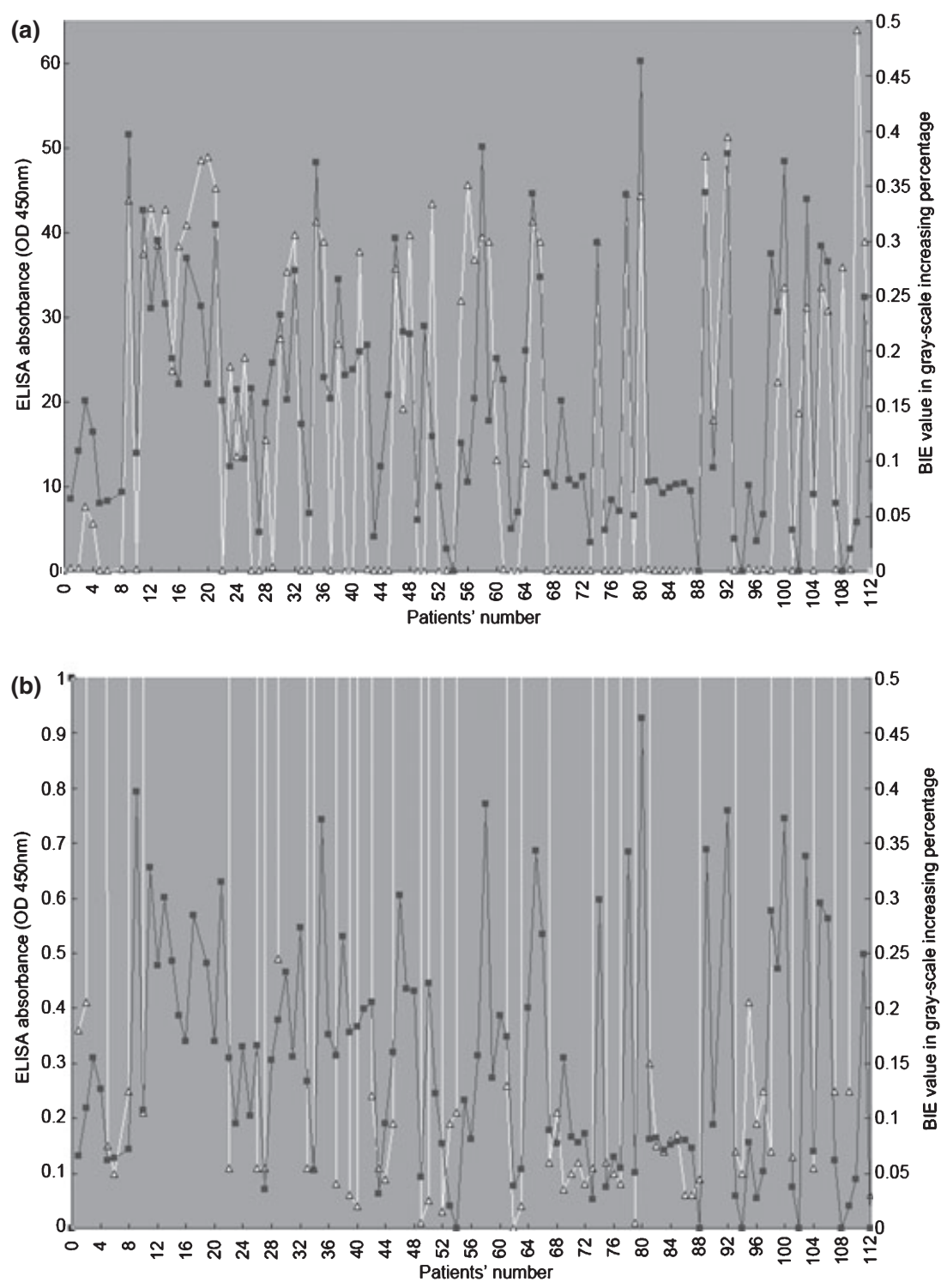
Table 3 HBsAg detection results of BIE and ELISA. Data of BIE were the variation of value in greyscale above the corresponding ligand control. Data of ELISA were the variation of OD above the corresponding ligand control

\begin{tabular}{lccccccccc}
\hline BIE & ELISA & BIE & ELISA & BIE & ELISA & BIE & ELISA & BIE & ELISA \\
\hline 0.07 & 0.36 & 0.10 & 25.3 & 0.22 & 19.2 & 0.16 & 0.07 & 0.38 & 51.3 \\
0.11 & 0.41 & 0.17 & 0.11 & 0.22 & 39.8 & 0.08 & 0.1 & 0.03 & 0.14 \\
0.16 & 7.51 & 0.04 & 0.11 & 0.05 & 0.01 & 0.08 & 0.12 & 0 & 0.1 \\
0.13 & 5.71 & 0.15 & 15.5 & 0.22 & 0.05 & 0.09 & 0.08 & 0.08 & 0.41 \\
0.06 & 0.15 & 0.19 & 0.49 & 0.12 & 43.4 & 0.03 & 0.11 & 0.03 & 0.19 \\
0.06 & 0.1 & 0.23 & 27.5 & 0.08 & 0.03 & 0.30 & 39 & 0.06 & 0.25 \\
0.07 & 0.25 & 0.16 & 35.4 & 0.02 & 0.19 & 0.04 & 0.12 & 0.29 & 0.14 \\
0.40 & 43.8 & 0.27 & 39.7 & 0 & 0.21 & 0.07 & 0.1 & 0.24 & 22.4 \\
0.11 & 0.21 & 0.13 & 0.11 & 0.12 & 32 & 0.05 & 0.08 & 0.37 & 33.6 \\
0.33 & 37.5 & 0.05 & 0.11 & 0.08 & 45.6 & 0.34 & 44.6 & 0.04 & 0.13 \\
0.24 & 42.9 & 0.37 & 41.3 & 0.16 & 36.9 & 0.05 & 0.01 & 0 & 18.7 \\
0.30 & 38.6 & 0.18 & 38.9 & 0.39 & 39.5 & 0.46 & 44.3 & 0.34 & 31.2 \\
0.24 & 42.7 & 0.16 & 0.08 & 0.14 & 38.9 & 0.08 & 0.3 & 0.07 & 0.11 \\
0.19 & 23.7 & 0.27 & 26.8 & 0.19 & 13.1 & 0.08 & 0.15 & 0.30 & 33.6 \\
0.17 & 38.4 & 0.18 & 0.06 & 0.17 & 0.26 & 0.07 & 0.14 & 0.28 & 30.8 \\
0.28 & 40.9 & 0.18 & 0.04 & 0.04 & 0 & 0.08 & 0.16 & 0.06 & 0.25 \\
0.24 & 48.5 & 0.20 & 37.7 & 0.05 & 0.04 & 0.08 & 0.17 & 0 & 35.9 \\
0.17 & 48.9 & 0.21 & 0.24 & 0.20 & 12.8 & 0.08 & 0.06 & 0.02 & 0.25 \\
0.31 & 45.3 & 0.03 & 0.11 & 0.34 & 41.3 & 0.07 & 0.06 & 0.04 & 64 \\
0.15 & 0.11 & 0.09 & 0.09 & 0.27 & 38.9 & 0 & 0.09 & 0.25 & 39 \\
0.09 & 24.2 & 0.16 & 0.19 & 0.09 & 0.12 & 0.34 & 49.1 & 0 & 0.06 \\
0.16 & 13.6 & 0.30 & 35.8 & 0.08 & 0.21 & 0.09 & 17.9 & & \\
\hline
\end{tabular}

tion of ligand (10 $\mu \mathrm{L}, 2 \mu \mathrm{L} / \mathrm{min}, 5 \mathrm{~min})$, blocking of substrate $(40 \mu \mathrm{L}, 2 \mu \mathrm{L} / \mathrm{min}, 20 \mathrm{~min})$, sample detection $(20 \mu \mathrm{L}, \quad 2 \mu \mathrm{L} / \mathrm{min}, 10 \mathrm{~min})$ and rinsing with deionized water between consecutive operation steps $(60 \mu \mathrm{L}, 20 \mu \mathrm{L} /$ min, $3 \mathrm{~min})$. Five markers from seven patients could be detected on a single substrate in $1 \mathrm{~h}$ or less. With this operation process, 109 samples (Table 2) were detected. The HBsAg detection results using BIE were compared with those of ELISA, as shown in Fig. 4, and Table 3. Regression analysis showed that the results were in quite good agreement between the two methods $(r=0.67>$ $\left.r_{0.01}=0.247\right)$. The degree of agreement between BIE and ELISA in detecting HBsAg, anti-HBs, HBeAg, anti-HBe and anti-HBc was $90.3 \%, 90.2 \%, 71.3 \%, 90.6 \%$ and $94.4 \%$ respectively.

Cut-off values for HBsAg and anti-HBs were derived from ROCC (Fig. 5). The CoV was determined by the value in greyscale above the corresponding ligand control. When both the positive likelihood ratio and Youden's index reached their maxima, the corresponding variation in grey-scale value was taken as the best $\mathrm{CoV}$ point [17], as shown in Fig. 5. If there were two maxima of the same value, the bigger variation in grey-scale value was taken as the best $\mathrm{CoV}$ point to avoid false positives. The values of $\mathrm{CoV}$ for HBsAg, anti-HBs, HBeAg, anti-HBe and anti-HBc were $15 \%, 18 \%, 15 \%, 20 \%$ and $15 \%$ respectively.

\section{DISCUSSION}

Ligand screening has applications in clinical diagnosis of hepatitis B and is also helpful for developing BIE. At present, various kinds of ligands have been produced by various factories, but their bioactivity has large diversity even among different lots of the same products. Most ligands are suited to conventional methods only, and few ligands match BIE. When the same marker is detected, different ligands on the substrate exhibit different bioactivity. Polyclonal antibody ligands cannot guarantee full sensitivity [18], and artificial ligands cannot exhibit entirely natural bioactivity. If a ligand has high bioactivity, it is possible to achieve higher sensitivity and efficiency, which can be verified by the HBsAg Elecsys assay [19]. If ligands were not screened, marker detection would have high false positive rates and low sensitivity, and thus ligand screenings are necessary for successful BIE.

Cut-off values and sensitivity are important for hepatitis B marker detection. CoVs can help us to distinguish strong positive, near cut-off and negative samples. ELISA kits have different $\mathrm{CoVs}$ for different markers and BIE also gives different CoVs, which are helpful in distinguishing each marker accurately. ELISA has detection limits as low as $1 \mathrm{ng} / \mathrm{mL}$ of HBsAg [20] and $10 \mathrm{mIU} / \mathrm{mL}$ of anti-HBs [21]. However, it must be noted that sensitivity for HBsAg detection has not been evidently improved in the last 10 years, and the most 


\begin{tabular}{|c|c|c|c|c|}
\hline $\begin{array}{c}\text { HBsAg detection } \\
\text { variation value } \\
\text { in gray-scale }\end{array}$ & TPF & FPF & $\begin{array}{l}\text { Positive } \\
\text { likelihood } \\
\text { ratio }\end{array}$ & $\begin{array}{l}\text { Youden's } \\
\text { idex }\end{array}$ \\
\hline $3 \%$ & 0.9615 & 0.8596 & 1.1185 & 0.1019 \\
\hline $5 \%$ & 0.9423 & 0.7719 & 1.2207 & 0.1704 \\
\hline $8 \%$ & 0.9423 & 0.2456 & 3.8365 & 0.6967 \\
\hline $10 \%$ & 0.9231 & 0.0526 & 17.5385 & 0.8704 \\
\hline $13 \%$ & 0.9038 & 0.0175 & 51.5192 & 0.8863 \\
\hline $15 \%$ & 0.9038 & 0.0175 & 51.5192 & 0.8863 \\
\hline $18 \%$ & 0.7885 & 0.0175 & 44.9423 & 0.7709 \\
\hline $20 \%$ & 0.7115 & 0.0175 & 40.5577 & 0.6940 \\
\hline $23 \%$ & 0.6346 & 0.0175 & 36.1731 & 0.6171 \\
\hline $25 \%$ & 0.5192 & 0.0175 & 29.5962 & 0.5017 \\
\hline $28 \%$ & 0.4423 & 0.0175 & 25.2115 & 0.4248 \\
\hline $30 \%$ & 0.3654 & 0.0000 & & 0.3654 \\
\hline $35 \%$ & 0.2115 & 0.0000 & & 0.2115 \\
\hline
\end{tabular}

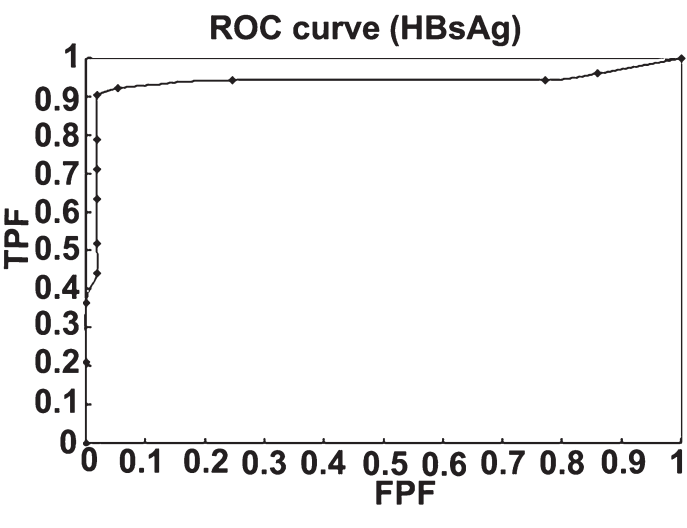

\begin{tabular}{|c|c|c|c|c|}
\hline $\begin{array}{c}\text { HBsAb detection } \\
\text { variation value } \\
\text { in gray-scale }\end{array}$ & TPF & FPF & $\begin{array}{c}\text { Positive } \\
\text { likelihood } \\
\text { ratio }\end{array}$ & $\begin{array}{c}\text { Youden's } \\
\text { idex }\end{array}$ \\
\hline $3 \%$ & 1.0000 & 1.0000 & 1.0000 & 0.0000 \\
\hline $5 \%$ & 1.0000 & 0.9310 & 1.0741 & 0.0690 \\
\hline $8 \%$ & 0.9804 & 0.8276 & 1.1846 & 0.1528 \\
\hline $10 \%$ & 0.9608 & 0.6724 & 1.4289 & 0.2884 \\
\hline $13 \%$ & 0.9412 & 0.3966 & 2.3734 & 0.5446 \\
\hline $15 \%$ & 0.9216 & 0.2414 & 3.8179 & 0.6802 \\
\hline $18 \%$ & 0.9020 & 0.1379 & 6.5392 & 0.7640 \\
\hline $20 \%$ & 0.8431 & 0.1034 & 8.1503 & 0.7397 \\
\hline $23 \%$ & 0.7255 & 0.0690 & 10.5196 & 0.6565 \\
\hline $25 \%$ & 0.6863 & 0.0517 & 13.2680 & 0.6346 \\
\hline $28 \%$ & 0.6275 & 0.0345 & 18.1961 & 0.5930 \\
\hline $30 \%$ & 0.5882 & 0.0345 & 17.0588 & 0.5538 \\
\hline $35 \%$ & 0.4706 & 0.0345 & 13.6471 & 0.4361 \\
\hline & & & & \\
\hline
\end{tabular}

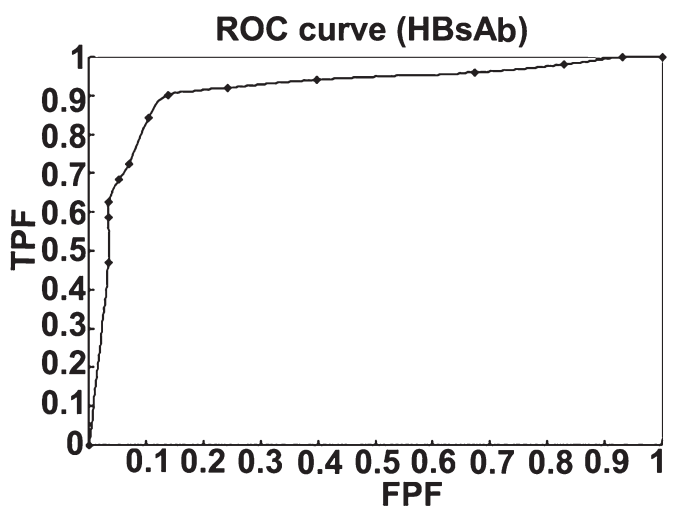

Fig. $5 \mathrm{CoVs}$ for HBsAg and anti-HBs detection. The variation in grey-scale values for HBsAg and anti-HBs detection is above the blank control of ligand. TPF is true positive fraction/rate; FPF is false positive fraction/rate; Positive likelihood ratio is TPF divided by FPF (TPF/FPF); Youden's index is TPF minus FPF (TPF - FPF). The CoV is indicated by the lines with dark background.

sensitive detection gained market approval in 1995 [22,23]. The HBsAg detection limit of newly licensed tests in Europe is now under $0.15 \mathrm{ng} / \mathrm{mL}$ (enzyme-linked fluorescent immunoassay) [24]. Compared with the label methods, although the sensitivity of BIE has already reached clinical standard, it is still at a low level, and further improvements in sensitivity are still needed.

Biosensor based on imaging ellipsometry is able to realize multiplexed analysis, a simplified process and short test time. It can detect five markers of several patients simultaneously in about $1 \mathrm{~h}$ and higher throughput is possible with an improved setup, whereas ELISA can detect only one marker on each plate over a longer test time (ligand immobilizing and assaying lasts 1-2 days). BIE allows us to test crude samples in a label-free method, with a simple process. Furthermore, contaminating spots can also be easily discerned with the help of visual BIE images to avoid false signals. Thus, BIE has some merits over ELISA.

In conclusion, BIE has potential in the detection of hepatitis B markers with an acceptable accuracy.

\section{ACKNOWLEDGEMENTS}

This study was supported by the Knowledge Innovation Program of the Chinese Academy of Sciences, Grant No.
KJCX2-YW-M04, -M03, National Basic Research Program of China 2009CB320302 and 863 programme. We thank Shandong Provincial Hospital and Tientsin Blood Disease Hospital for providing relevant samples.

\section{REFERENCES}

1 Chen Y, Wu W, Li L, Lou B, Zhang J, Fan J. Comparison of the results for three automated immunoassay systems in determining serum HBV markers. Clin Chim Acta 2006; 372(1-2): 129-133.

2 Moriya T, Kuramoto I, Yoshizawa H, Holland P. Distribution of hepatitis B virus genotypes among American blood donors determined with a PreS2 epitope enzyme-linked immunosorbent assay kit. J Clin Microbiol 2002; 40(3): 877-880.

3 Almeida R, Cardoso D. Detection of HBV DNA by nestedPCR in a HBsAg and anti-HBc negative blood bank donor. J Clin Virol 2006; 36(3): 231-234.

4 Wang Y, Shen J, Liu H. Analytical performance of and real sample analysis with an HBV gene visual detection chip. J Virol Methods 2004; 121(1): 79-84.

5 Chen Z, Wang K, Yang X et al. Determination of hepatitis B surface antigen by surface plasmon resonance biosensor. Acta Chim Sin 2003; 61(1): 137-140.

6 Pál J, Pálinkás L, Nyárády Z et al. Sandwich type ELISA and a fluorescent cytometric microbead assay for quantitative 
determination of hepatitis B virus $\mathrm{X}$ antigen level in human sera. J Immunol Methods 2005; 306(1-2): 183-192.

7 Jin G, Tengvall P, Lundstrom I, Arwin H. A biosensor concept based on imaging ellipsometry for visualization of biomolecular interactions. Anal Biochem 1995; 232(1): 69-72.

8 Zhang H, Qi C, Wang Z, Jin G, Xiu R. Evaluation of a new CA15-3 protein assay method: optical protein-chip system for clinical application. Clin Chem 2005; 51(6): 1038-1040.

9 Bae Y, Park K, Oh B, Lee W, Choi J. Immunosensor for detection of Salmonella typhimurium based on imaging ellipsometry. Colloids Surf A Physicochem Eng Asp 2005; 257-258(1): 19-23.

10 Qi C, Feng J, Wang Z, Meng Y, Yan X, Jin G. Application of optical protein-chip in detecting phage M13KO7. Chin J Biotechnol 2006; 22(5): 856-860.

11 Qi C, Duan J, Wang Z et al. Investigation of interaction between two neutralizing monoclonal antibodies and SARS virus using biosensor based on imaging ellipsometry. Biomed Microdevices 2006; 8(3): 247-253.

12 Wang Z, Jin G. A label-free multisensing immunosensor based on imaging Ellipsometry. Anal Chem 2003; 75(22): 6119-6123.

13 Jin G, Zhao Z, Wang Z et al. The Development of Biosensor with Imaging Ellipsometry. The 26th Annual International Conference of the IEEE EMBS. San Francisco: IEEE, 2004. 1975-1978.

14 Wang Z, Meng Y, Ying P, Qi C, Jin G. A label-free protein microfluidic array for parallel immunoassays. Electrophoresis 2006; 27(20): 4078-4085.

15 Arwin H, Welinklinstorm S, Jansson R. Off-null ellipsometry revisited: basic considerations for measuring surface concentrations at solid/liquid interfaces. J Colloid Interface Sci 1993; 156(2): 377-382.
16 Stenberg M, Nygren H. The use of the isoscope ellipsometer in the study of adsorbed proteins and biospecific binding reactions. J Phys 1983; 44(1): 83-86.

17 Metz C. Some practical issues of experimental design and data analysis in radiological ROC studies. Invest Radiol 1989; 24(2): 234-245.

18 Waters J, Kennedy M, Voet P et al. Loss of the common "A" determinant of hepatitis B surface antigen by a vaccine induced escape mutant. J Clin Invest 1992; 90(6): 25432547.

19 Weber B, Melchior W, Gehrke R, Doerr H, Berger A, Rabenau $\mathrm{H}$. Hepatitis B virus markers in anti-HBc only positive individuals. J Med Virol 2001; 64(3): 312-319.

20 Liu F, Liu F, Zhuo R, Peng Y, Deng Y, Zeng Y. Development of a polymer-enzyme immunoassay method and its application. Biotechnol Appl Biochem 1995; 21(3): 257264.

21 Hu B, Liang M, Hong G, Li Z, Zhu Z, Li L. Expression of hepatitis B virus $S$ gene in pichia pastoris and application of the product for detection of anti-HBs antibody. J Biochem Mol Biol 2005; 38(6): 683-689.

22 Nick S, Soboll H, Unger G et al. Results of the Re-evaluation of HIV, HCV and HBsAg Screening Tests by the Paul-Ehrlich-Institut. Progress in Clinical Virology IV. Hamburg: European Society for Clinical Virology, 1998.

23 Scheiblauer H, Soboll H, Nick S. Evaluation of 17 CE-marked HBsAg assays with respect to clinical sensitivity, analytical sensitivity, and hepatitis B virus mutant detection. J Med Virol 2006; 78 (Suppl. 1): 66-70.

24 Weber B, Van der Taelem-Brule N, Berger A, Simon F, Geudin M, Ritter J. Evaluation of a new automated assay for hepatitis B surface antigen (HBsAg) detection VIDAS HBsAg Ultra. J Virol Methods 2006; 135(1): 109-117. 